\title{
25-Hydroxycholesterol exerts both a cox-2-dependent transient proliferative effect and cox-2-independent cytotoxic effect on bovine endothelial cells in a time- and cell-type-dependent manner
}

\author{
Journal of Angiogenesis Research 2:24 I DOI: 10.1186/2040-2384-2-24 I C Li et al.; licensee Publiverse \\ Online S.R.L. 2010 \\ Received: 1 Aug 2010 | Accepted: 11 Aug 2010 | Published: 11 Aug 2010 \\ Nguyen Vicky PKH, Chen Stephen H, Pizzuto Katerina, Cantarutti Alyssa ${ }^{+}$, Terminesi Alyssa ${ }^{+}$, \\ Mendonca Cassandra ${ }^{+}$, Dumont Daniel J ${ }^{@}$ \\ ${ }^{+}$Contributed equally ${ }^{@}$ Corresponding author
}

\section{Abstract}

\section{Background}

25-hydroxycholesterol (25-OHC) is a product of oxidation of dietary cholesterol present in human plasma. 25-OHC and other oxidized forms of cholesterol are implicated in modulating inflammatory responses involved in development of atherosclerosis and colon carcinogenesis.

\section{Methods}

Primary lymphatic, venous and arterial endothelial cells isolated from bovine mesentery (bmLEC, bmVEC, bmAEC) were treated with $25-\mathrm{OHC}$ and tested for several different cellular parameters.

\section{Results}

We found 25-OHC to be a potent inducer of cyclooxygenase-2 (Cox-2, prostaglandin G-H synthase-2) expression in bovine mesenteric lymphatic, venous, and arterial endothelial cells. The induction of Cox-2 expression in endothelial cells by $25-\mathrm{OHC}$ led to an initial increase in cellular proliferation that was inhibited by the Cox-2 selective inhibitor celecoxib (Celebrex). Prolonged exposure to 25-OHC was cytotoxic.

Furthermore, endothelial cells induced to express Cox-2 by 25-OHC were more sensitive to the effects of the Cox-2 selective inhibitor celecoxib (Celebrex). These results suggest that some effects of 25-OHC on cells may be dependent on Cox-2 enzymatic activity.

\section{Conclusions}

Cox-2 dependent elevating effects of 25-OHC on endothelial cell proliferation was transient. Prolonged exposure to $25-\mathrm{OHC}$ caused cell death and enhanced celecoxib-induced cell death in a cell-type dependent manner. The lack of uniform response by the three endothelial cell types examined suggests that our model system of primary cultures of bmLECs, bmVECs, and bmAECs may aid the evaluation of celecoxib in inhibiting proliferation of different types of tumour-associated endothelial cells.

\section{Background}

The enzyme cholesterol-25-hydroxylase $(\mathrm{CH} 25 \mathrm{H})$ converts dietary cholesterol to 25-hydroxycholesterol (25$\mathrm{OHC}$, cholest-5-ene-3 $\beta, 25$-diol) in a variety of tissues including heart, lungs, kidney [ 1,2], and intestinal 
epithelium [ 3]. As reviewed by Javitt, 25-OHC only plays a minor role (approximately 5\%) in bile acid synthesis in the liver and may play a more active role as a ligand in the regulation of cholesterol synthesis and transport [ 4]. Indeed, 25-OHC has been detected in blood plasma [ 5] suggesting that it may have systemwide effects in the body, although the biochemical function of $25-\mathrm{OHC}$ has not been fully elucidated.

Some observations of the effects of 25-OHC include: inhibition of 3-hydroxy-3-methyhydroxy-CoA (HMG$\mathrm{CoA}$ ) reductase activity correlating with reduction in mouse cultured fetal liver cell growth [6]; and inhibition of sterol regulatory element-binding proteins (SREBPs) [ 7]. HMG-CoA reductase and SREBPs are key players in the synthesis of cholesterol and other isoprenoids in the cell--HMG-CoA catalyses the ratedetermining step and SREBPs are transcription factors promoting the expression of genes involved in the process [ 8]. Thus, 25-OHC is thought to attenuate cholesterol and steroid lipid biosynthesis, down-regulation of which is potentially linked to observations that 25-OHC exposure causes cell-cycle arrest and inhibits growth in immortalized and transformed A31 mouse embryonic cells [ 9], and human primary prostate stromal cells in culture [10].

Potentially unrelated to the role of $25-\mathrm{OHC}$ in regulating cholesterol and isoprenoid synthesis are observations that 25-OHC induces apoptosis in the human acute lymphoblastic leukemia cell line, CEM, by suppression of c-myc expression [ 11, 12], in mouse macrophage-like P388-D1 cells by suppression of the cysteine protease, CPP32 [ 13], and in hamster ovarian CHO-K1 cells by caspase activation [14]. Likewise, the induction of cyclooxygenase-2 (Cox-2, prostaglandin G-H synthase-2) expression in cultured bovine coronary artery endothelial cells (ECs) does not depend on the activity of Cytochrome P450 (CYP), which are enzymes essential for cholesterol and isoprenoid biosynthesis [ 15]. Similar observations were noted in rabbit pulmonary arterial ECs and smooth muscle cells (SMCs) exposed to 25-OHC. Treatment with 25-OHC resulted in increased synthesis of eicosanoid products of the arachidonic acid oxidation pathway partly catalyzed by Cox-1 and -2 enzymes [ 16]. These observations contribute to the idea that 25-OHC play many roles in cell biology that are only beginning to be elucidated.

Whereas 25-OHC treatment leads to induction of Cox-2 expression [ 15,16$]$, treatment of cells with selective inhibitors to Cox-2 has been shown to induce cell death in endothelial progenitor cells (EPCs) [17], and to induce cell-cycle arrest in ECs [ 18]. The latter observations would suggest that 25-OHC treatment should promote Cox-2 expression and thereby should contribute to cellular proliferation. However, studies such as by Larsson and colleagues [9] and Wang and colleagues suggest the opposite outcome [10].

In order to understand effects of 25-OHC on cells, we exposed cultured primary bovine lymphatic and blood ECs (bmECs), that do not normally express Cox-2, to 25-OHC. We found 25-OHC to induce Cox-2 expression in primary cultured bovine mesenteric lymphatic, venous, and arterial ECs (bmLECs, bmVECs, bmAECs), correlating with an initial increase in cell count. Exposure of 25-OHC treated bmECs to the Cox2 -selective inhibitor celecoxib (Celebrex) inhibited the observed short burst of increase in cell count. We found bmECs to be able to tolerate short exposures to low levels of 25-OHC. However, prolonged exposure to $25-\mathrm{OHC}$ resulted in cell death, which was more pronounced in bmECs treated with celecoxib. These results suggest some effects of 25-OHC may be dependent upon Cox-2 enzyme activity in ECs.

\section{Methods}

\section{Cell Culture and 25-OHC Treatment}

Primary bmLECs, bmVECs, and bmAECs were from frozen stocks of bmECs previously isolated and described by Nguyen and colleagues [ 19]. Human colorectal carcinoma cell line HCT-116 was obtained from ATCC (American Type Culture Collection) and ECCC and grown according to provided instructions. BmECs were grown in standard tissue culture conditions in Dulbecco's Modified Eagle's Medium (DMEM, Sigma Aldrich) supplemented with $10 \%$ fetal bovine serum (FBS, Sigma Aldrich). For all experiments involving treatment with 25-OHC and/or celecoxib, dialyzed FBS (Gibco). $5 \mu \mathrm{M}$ Celecoxib was used unless otherwise stated.

In all relevant experiments, the concentration of 25-OHC (dissolved in ethanol (EtOH), Sigma Aldrich) was kept constant at $25 \mu \mathrm{M}$ as previously described by Wohlfiel and Campbell [ 15] to be effective for induction of Cox-2 expression. Wherever indicated, short exposure of cells to 25-OHC means at most 24 hours, and prolonged exposure means at least 48 hours. 
Total RNA was prepared from bmECs using Tri-Reagent (Sigma Aldrich) according to manufacturer's instructions. cDNA was synthesized from $1 \mu \mathrm{g}$ of total RNA with Thermoscript Reverse Transcriptase (Invitrogen) according to manufacturer's instructions. PCR was performed with Taq polymerase (Qiagen) with primer sequences: Coxl (forward primer 5'-CTGTTGTTACTATCCATGCC-3', reverse primer 5'CTGGAAAAGCTGCTCATCGC-3'), Cox2 (forward primer 5'-GAGAAAACTGCTCAACACCG-3', reverse primer 5'-GCATACTCTGTTGTGTTCCC-3'), GAPDH (forward primer 5'-ACC ACA GTC CAT GCC ATC AC-3', reverse primer 5'-TCC ACC ACC CTG TTG CTG TA-3').

\section{Viable Cell Counting}

Cell counts were done using a hemocytometer. Cells were stained with 0.08\% Trypan Blue (Gibco) after trypsin (Gibco) treatment. Eight $\mu \mathrm{L}$ of the cell suspension was loaded into each side of the haemocytometer. Four squares with similar cell distribution were counted. Blue (non-viable) cells were excluded from tally. All experiments were done in at least duplicates and repeated at least twice.

\section{Quantification of Cell Death by ELISA}

Cells were incubated with $25 \mu \mathrm{M} 25-\mathrm{OHC}$ and/or celecoxib at various concentrations for at least 60 hours before harvesting. Cell death was quantified using the Cell Death Dectection ELISA-Plus kit (Roche) according to manufacturer's instructions. Amount of coloured immobilized antibodies-histone complexes was determined by spectrophotometric absorbance reading at $405 \mathrm{~nm}$ with wavelength correction set at $509 \mathrm{~nm}$.

\section{Statistical Analysis}

Hypothesis testing by appropriate statistical tests was done on all sets of data. P-values were calculated using paired or unpaired, 1 or 2-tailed, student t-test or ANOVA when appropriate, with the confidence interval set at $95 \%(\alpha=0.05)$.

\section{Results}

\section{5-OHC induces Cox-2 expression}

As previously described by Wohlfeil and Campbell [ 15, 16], 25-OHC stimulates expression of Cox-2 in cultured ECs. Wohlfeil and Campbell exposed bovine coronary arterial cells to a concentration of $10 \mu \mathrm{g} / \mathrm{mL}$ $(25 \mu \mathrm{M})$ of $25-\mathrm{OHC}$ for 48 hours. To determine whether 25 -OHC similarly induces Cox- 2 expression our bmLECs, bmVECs, and bmAECs, we treated ECs with $25 \mu \mathrm{M}$ added directly to culture media and left overnight. By RT-PCR, bmLECs and bmAECs expressed Cox-2 in the presence of 25-OHC but not in ethanol $(\mathrm{EtOH})$ vehicle alone. Cox-1, however, was constitutively expressed in all three cell types (Figure 1A). Interestingly, basal level of Cox-2 was high in bmVECs but not in bmAECs or bmLECs. Cox-2 levels increased significantly upon treatment of bmVECs with 25-OHC. Thus, these results corroborate those reported by Wohlfeil and Campbell [ 15,16$]$.

\section{Figure 1}


A

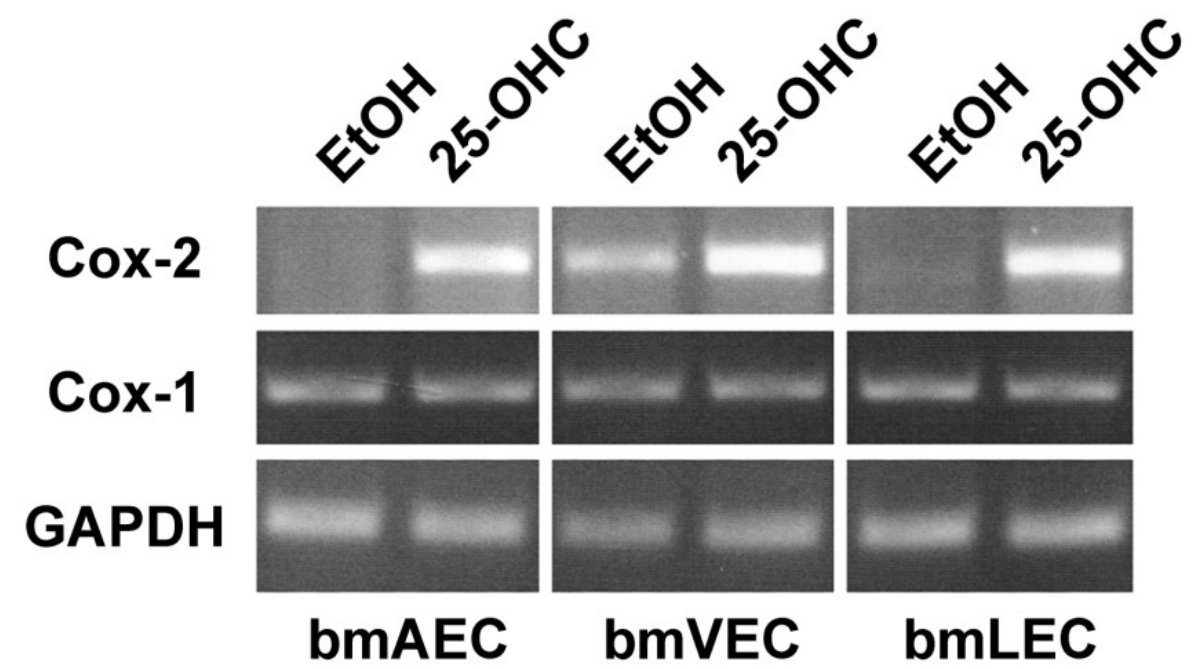

B

\title{
EtOH Vehicle
}

25-OHC
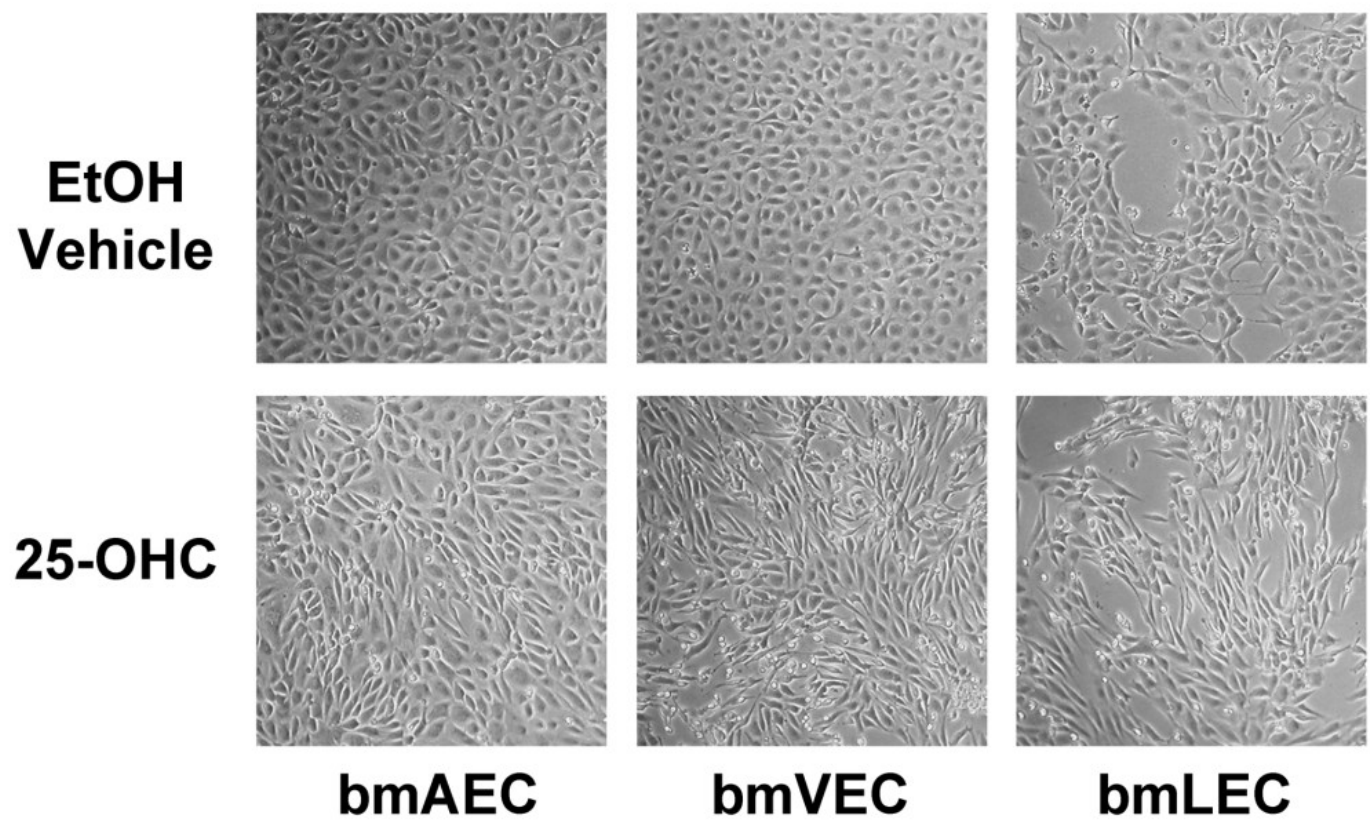

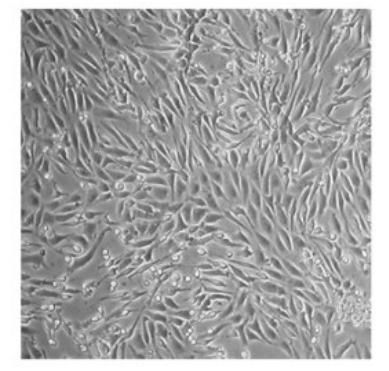

bmVEC

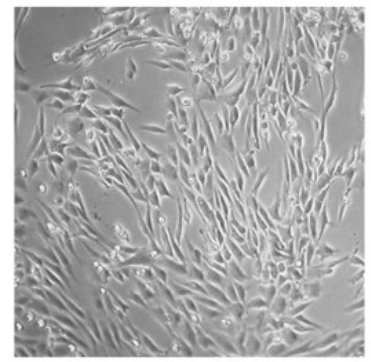

bmLEC

\begin{abstract}
Expression of Cox 2 in mesenteric ECs. A/25-OHC exposure induced Cox-2 expression in bmECs. ECs were treated with $25 \mu \mathrm{M}$ of $25-\mathrm{OHC}$ added directly to culture media and left overnight before mRNA harvest and RT-PCR. BmLECs and bmAECs expressed Cox-2 in the presence of 25-OHC but not in EtOH vehicle alone. Cox-1, however, was constitutively expressed in all three cell types. Basal level of Cox-2 was high in bmVECs but not in bmAECs or bmLECs. Cox-2 levels increased significantly upon treatment of bmVECs with 25-OHC. B/25-OHC exposure changed morphology cultured bmECs. ECs lost the typical endothelial cobble-stoned morphology and became elongated, forming partial swirls in the presence of $25-\mathrm{OHC}$ but not in vehicle control.
\end{abstract}

Further corroborating results reported by Wohlfeil and Campbell [ 15], who found 25-OHC to cause cultured rabbit pulmonary arterial ECs and SMCs to take on an elongated morphology, we also found changes in morphology of our cultured bmECs. BmECs lost the typical endothelial cobble-stoned morphology and became elongated, forming partial swirls in the presence of 25-OHC (Figure 1B ).

\section{Short 25-OHC exposure promotes proliferation}

In addition to the changed morphology, we observed that plates of cells treated with $25-\mathrm{OHC}$ for 24 hours or less appeared to be more tightly packed with cells than those treated with ethanol vehicle alone. We also observed some ECs loosely attached to and growing outside the monolayer (Figure 1b). Without 25-OHC treatment, all three bmECs formed a monolayer in culture with flat cells touching at all sides without squeezing tightly together. This observation led us to hypothesize that perhaps there was an increase in the number of cells packed in the monolayer. Indeed, we found this to be the case when we counted the cells after 
24 hours of growing cells in 25-OHC (Figure 2a). Interestingly, the fold difference in the number of viable cells from seeded cells (taken as 1 in figure $2 \mathrm{a}$ ) seemed most pronounced in bmLECs compared to bmVECs and bmAECs (Figure 2a).

Figure 2
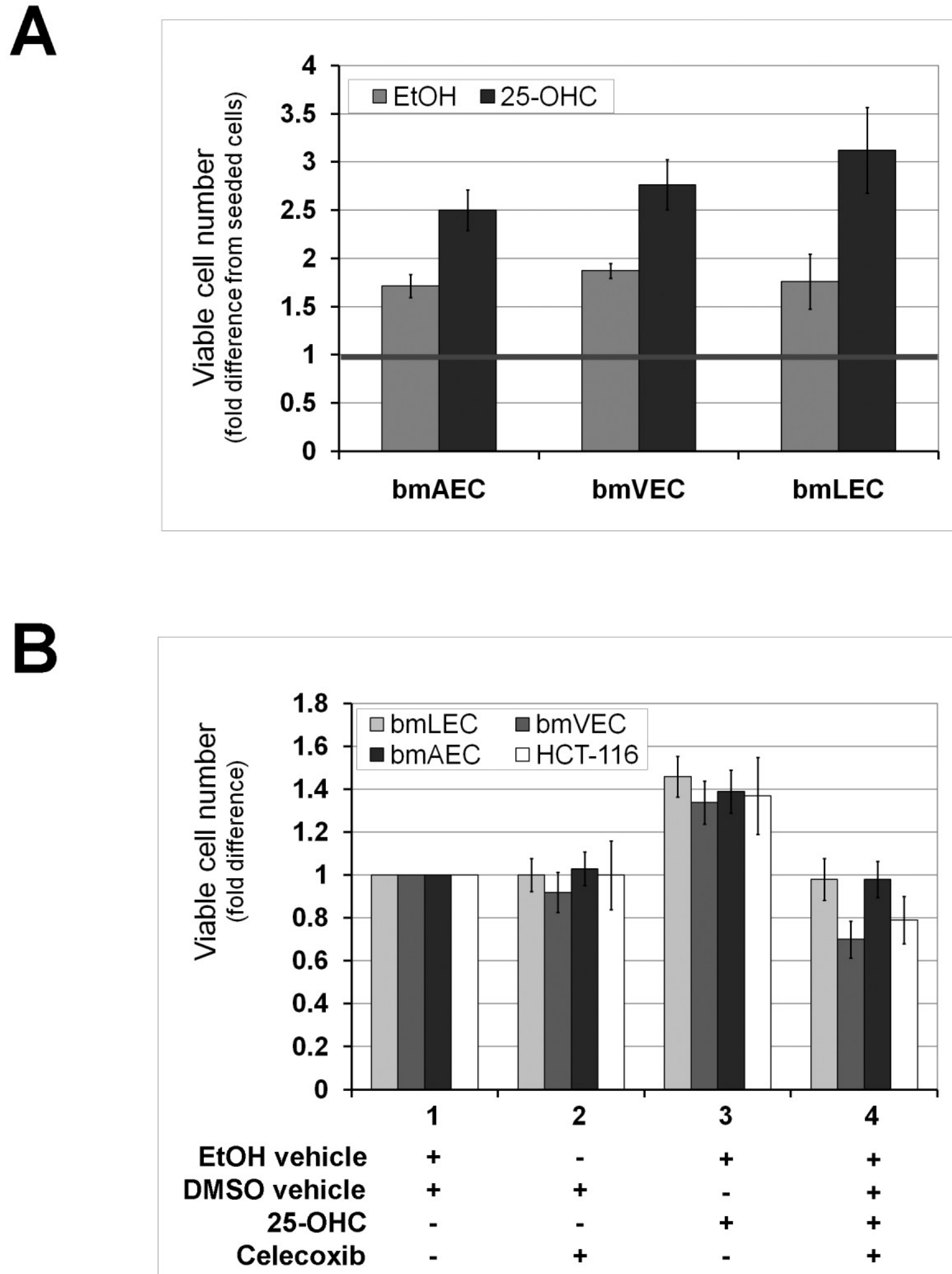
difference in the number of viable cells from seeded cells (taken as 1) was most pronounced in bmLECs compared to bmVECs and bmAECs. Mean of fold differences between treated and untreated bmAEC, bmVEC, and bmLEC from three trials analysed by t-test yielded p-values of $0.021,0.016$, and 0.0036 respectively $(\mathrm{n}=3)$. $\mathrm{B} /$ Temporary boost in EC proliferation due to 25-OHC exposure for 12 hours was dependent on Cox-2 activity. ECs were treated with the selective Cox-2 inhibitor celecoxib for 12 hours after 25-OHC exposure. Celecoxib $(5 \mu \mathrm{M})$ reversed the small increase in cell number of viable cells due to 25-OHC. The number of viable bmVECs treated with celecoxib alone dropped below the number of viable vehicle-treated bmVECs. Proliferative effects of $25-\mathrm{OHC}$ also applied to human colorectal carcinoma cells HCT-116. HCT-116 has previously shown to be Cox-2 deficient. For each cell type, mean of fold differences between treatments from three trials analysed by ANOVA generated p-values $\leq 0.001$ $(n=3)$. For each treatment with celecoxib, 25-OHC, and both together, the mean fold differences between each cell type analysed by ANOVA generated p-values of $0.084,0.011$, and 0.00038 , respectively $(\mathrm{n}=3)$.

To determine whether the increase in cell count was dependent on Cox-2 enzyme activity, we treated cells with the selective Cox-2 inhibitor celecoxib (Celebrex) after 25-OHC exposure. When cells were treated with $25-\mathrm{OHC}$ in the presence of celecoxib for 12 hours, cell counts were the same as vehicle alone (Figure $2 \mathrm{~b}$ ). Particularly noteworthy was the count of bmVECs treated with celecoxib: the number of viable bmVECs dropped below the count of vehicle treated bmVECs (Figure $2 \mathrm{~b}$ ). bmVECs seemed to be more sensitive to celecoxib in culture media than bmAECs or bmLECs. This observation is in agreement with PCR results shown in figure 1a, where a high basal level of Cox-2 transcript was clearly present in vehicle-treated bmVECs but not in bmAECs or bmLECs; Cox-2 enzyme activity may play a role in the growth of bmVECs in culture.

To determine whether proliferative effects of $25-\mathrm{OHC}$ on cells was restricted ECs, we subjected the human colorectal carcinoma cells HCT-116 to the same treatments as the bmECs (Figure 2b). HCT-116 has previously been shown to be Cox-2 deficient by Molina and colleagues [ 20]. We found treatment of HCT116 with $25-\mathrm{OHC}$ increased viable cell count and the increase to be reversed by celecoxib as observed in bmECs (Figure $2 \mathrm{~b}$ ). Therefore the proliferative effects of $25-\mathrm{OHC}$ on cells was not restricted to primary ECs but also applicable to colorectal carcinoma cells in culture.

\section{Prolonged exposure to 25-OHC treatment caused cell death}

Although 25-OHC gave bmECs a boost in cellular proliferation, primary bmECs did not lose contact inhibition. When ECs reached confluency after seeding, they stopped growing even in the presence of 25OHC. Whether cells were confluent or still proliferating, we observed that continued exposure to 25-OHC past 60 hours caused the cells to undergo cell death (Figure 3). The level of cell death was measured at 72 hours by an ELISA assay quantifying DNA fragmentation. BmAECs were significantly more susceptible to cell death induced by prolonged 25-OHC exposure than either bmVECs or bmLECs. Furthermore, we were not able to rescue the cells by inhibiting Cox-2 activity with $5 \mu \mathrm{M}$ celecoxib (Figure 3 ). This result suggests that cell death induced by prolonged 25-OHC exposure was not dependent on Cox- 2 enzyme activity.

Figure 3 

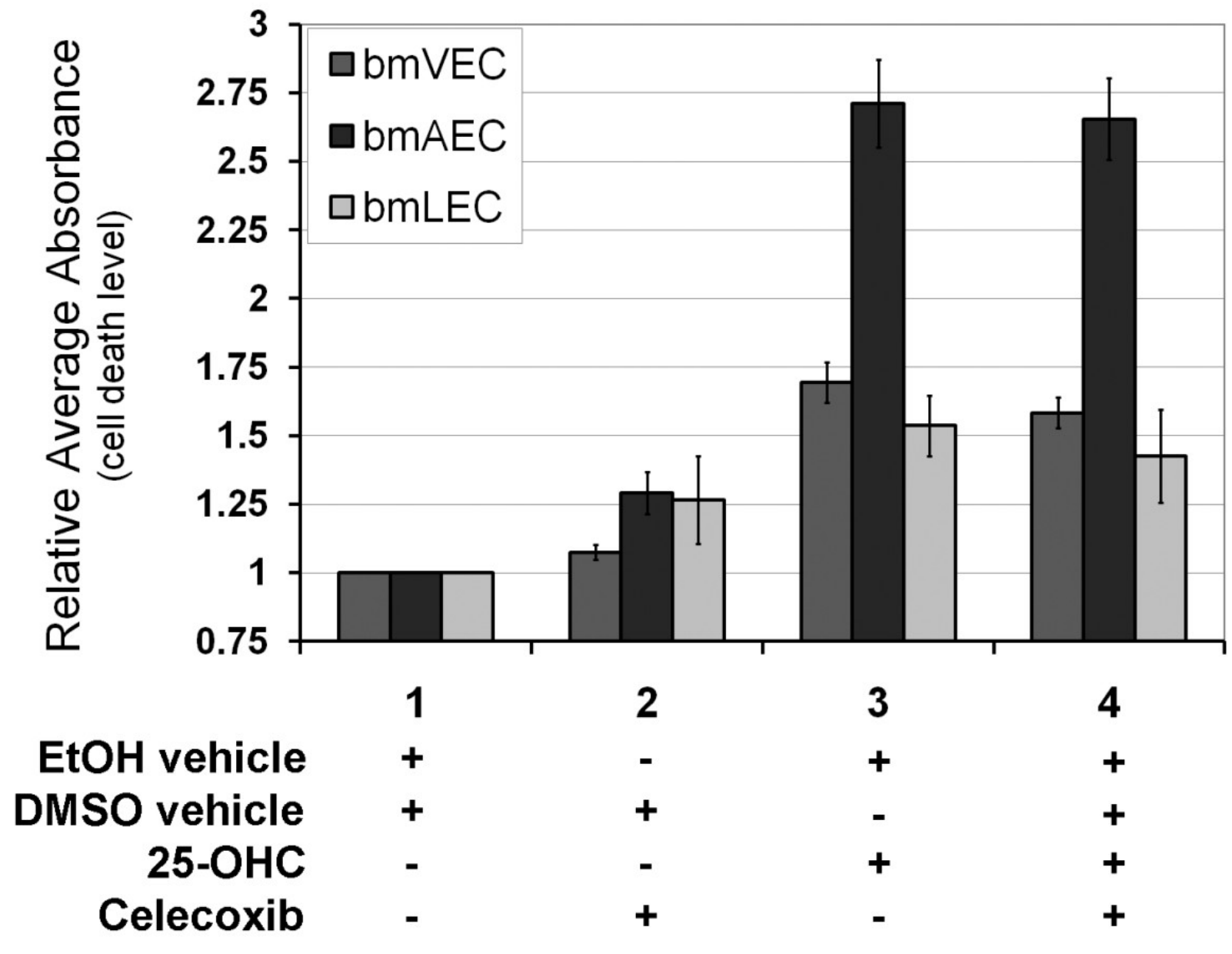

Long-term exposure to 25-OHC is toxic to ECs. Exposure to 25-OHC past 60 hours caused the cells to undergo cell death. Levels of EC death due to $25-\mathrm{OHC}$ was measured at 72 hours by ELISA assay quantifying DNA fragmentation. BmAECs were significantly more susceptible to cell death induced by prolonged 25-OHC exposure than either bmVECs or bmLECs. Celecoxib at $5 \mu \mathrm{M}$ did not reverse the cell death.

\section{8 hour exposure to 25-OHC sensitizes cells with undetectable basal levels of Cox-2 to effects of Celecoxib}

Low doses of celecoxib (5-10 $\mu \mathrm{M})$ have been shown to induce G2/M cell cycle arrest through inhibition of Cox-2 dependent prostaglandin E2 production [ 21]. In order to compare the effects of celecoxib on cells with undetectable basal levels of Cox-2 and cells induced to express detectable levels of Cox-2, we performed cell counts with trypan blue after growing cells for a period of 48 hours in the presence of low doses of celecoxib. We chose 48 hours because exposure of bmECs to 25-OHC over this period of time was not long enough to result in toxic effects leading to massive cell death as measured in Figure 3 . Furthermore the initial growth advantage conferred on cells by 25-OHC induction of Cox-2 shown in Figure 1 was no longer detectable after 48 hours due to contact inhibition. Low dose celecoxib caused the same reduction in viable bmLEC cell numbers whether or not $25-\mathrm{OHC}$ was present (Figure $4 \mathrm{a}$ ). Unlike bmLECs, viable numbers of bmVECs not treated with 25-OHC did not change as a result of treatment with celecoxib until the concentration was above $5 \mu \mathrm{M}$ (Figure 4a). Unlike either bmVECs or bmLECs, even $5 \mu \mathrm{M}$ of celecoxib reduced viable bmAEC cell counts, which was reduced to a greater extent in the presence of 25-OHC (Figure $4 \mathrm{~b}$ ). Treatment of bmAECs with $50 \mu \mathrm{M}$ of celecoxib in the presence of 25-OHC caused massive cell death reducing viable cell numbers to below one-fifth of vehicle control. These results indicate that each bmEC type exhibited different levels of sensitivity to celecoxib with or without 25-OHC treatment.

\section{Figure 4}


A

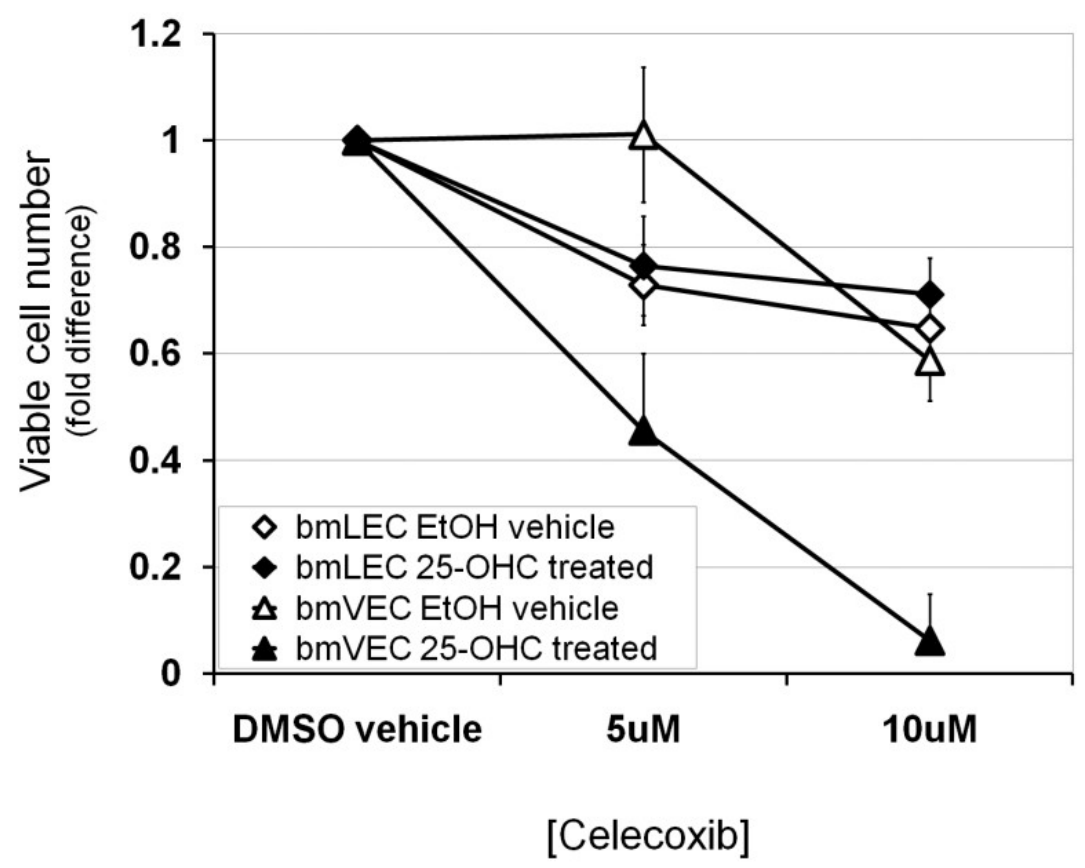

B
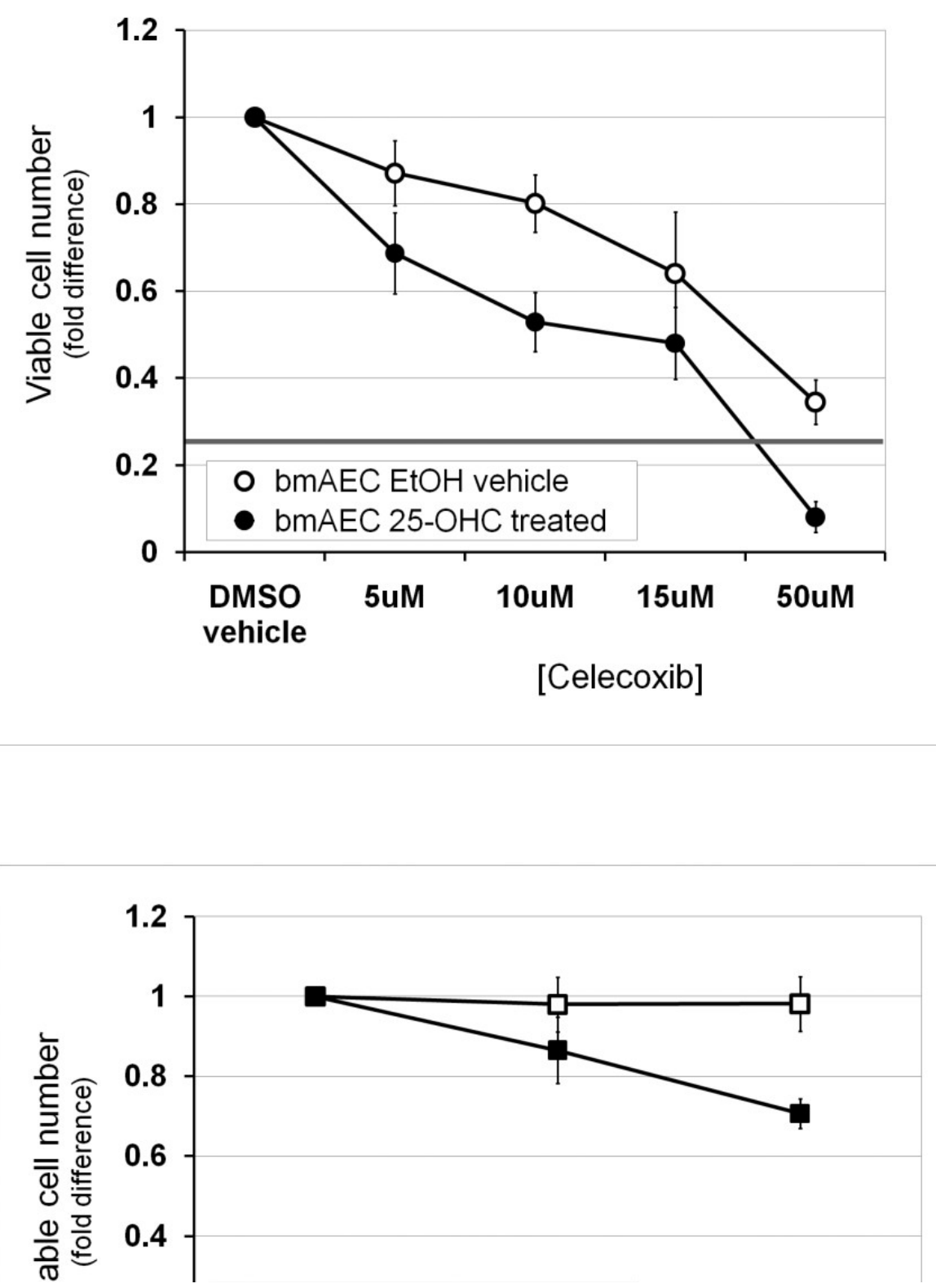
48 hour exposure to 25-OHC sensitized Cox-2-negative cells to effects of Celecoxib. A/Celecoxib concentrations of 5 and $10 \mu \mathrm{M}$ caused the same reduction in viable cell numbers of bmLECs whether or not 25-OHC was present. Unlike bmLECs, viable numbers of bmVECs not treated with 25-OHC did not change as a result of treatment with celecoxib until the concentration was above $5 \mu \mathrm{M}$. Mean of fold differences between EtOH-treated (vehicle, 25-OHC untreated) bmLECs and bmVECs in the presence of $5 \mu \mathrm{M}$ celecoxib analysed by t-test generated p-value of $0.0005(n=4)$. B/Unlike either bmVECs or bmLECs, even $5 \mu \mathrm{M}$ of celecoxib statistically significantly reduced viable bmAEC cell counts slightly ( $\mathrm{p}$ $=0.012, \mathrm{n}=4$ ). Cell count was reduced to a greater extent in the presence of 25-OHC. Mean fold differences between $25-\mathrm{OHC}$ treated and 25-OHC untreated bmAECs at $10 \mu \mathrm{M}$ analysed by t-test generated p-value of $0.0004(n=4)$. C/Low doses of celecoxib also increased reduction in viable cell counts of colorectal carcinoma cells HCT-116 (previously shown to be Cox-2 deficient) in the presence of 25-OHC. Unlike ECs, viable HCT-116 cell numbers did not differ from vehicle control in the absence of 25-OHC. Mean fold difference between cell counts of HCT-116 treated and not treated with 25-OHC analysed by t-test generated $\mathrm{p}$-value of 0.029 at $5 \mu \mathrm{M}$ celecoxib, and a p-value of 0.0006 at $15 \mu \mathrm{M}(\mathrm{n}=3)$.

To determine whether low doses of celecoxib also increased reduction in viable cell counts of colorectal carcinoma cells with undetectable basal Cox-2 expression, we performed the same experiment on colorectal carcinoma cells HCT-116 previously shown to be Cox-2 deficient [ 20]. Unlike ECs, in the absence of 25OHC, viable HCT-116 cell numbers did not differ from vehicle control even at $10 \mu \mathrm{M}$ of celecoxib (Figure $4 \mathrm{c})$. In the presence of 25-OHC, HCT-116 viable cell numbers reduced as celecoxib concentrations increased from $5 \mu \mathrm{M}$ to $15 \mu \mathrm{M}$ (Figure 4c). These results indicate that increased sensitivity to effects of celebrex as a result of 25-OHC exposure was not restricted to primary ECs with undetectable basal levels of Cox-2 but also applicable to Cox-2-deficient colorectal carcinoma cells in culture.

\section{Discussion}

We set out in this study to elucidate the effects of 25-OHC on mammalian cells and to determine whether those effects are dependent on Cox-2. We found as previously reported by Wohlfeil and Campbell [ 15, 16] that $25-\mathrm{OHC}$ induces Cox-2 expression. We found that short exposure to $25-\mathrm{OHC}$ to induce Cox-2 led to a temporary increase in viable cell numbers that was reversed by the Cox-2 inhibitor celecoxib. Low dose of celecoxib used $(5 \mu \mathrm{M})$ ensured that non-specific binding of celecoxib to other targets was minimized-celecoxib is selective for Cox-2 at $5 \mu \mathrm{M}$, below previously reported IC ${ }_{50}$ value of $15 \mu \mathrm{M}$ for celecoxib binding to Cox-1 (reviewed in [22]). Contrastingly, the addition of celecoxib did not prevent cell death following prolonged exposure to 25-OHC. These results suggest that not all effects of 25-OHC on cells were dependent on Cox-2 activity.

Bovine cells have previously been established as acceptable model cells for studies involving Cox-2 inhibitors intended for human use. For example, Jung et al (2007) used bovine aortic endothelial cells to demonstrate anti-cancer properties of the Cox-2 inhibitor enoic acanthoic acid [23]. For another example, Toker et al (2008) demonstrated the relaxant effects of celecoxib on bovine ciliary muscle [24]. Most significantly, Myers et al (2010) demonstrated that bovine cells respond to non-steroidal anti-inflammatory drugs (NSAIDs) intended for human use similarly to other mammalian cells in suppressing Cox-2 activity [ 25]. Bovine ECs are therefore highly suitable cell models for studies such as described herein.

25-OHC is detected in human plasma at concentrations ranges of 0 to $11 \mathrm{ng} / \mathrm{mL}$ [ 5], however, cultured testicular macrophages have been shown to be capable of producing high levels of 25 -OHC comparable to the quantity chosen in the present study $(10 \mu \mathrm{g} / \mathrm{mL})$ [ 26]. Nes et al (2000) reported cultured testicular macrophages were capable of producing $10 \mathrm{fg} 25-\mathrm{OHC}$ per cell per hour [ 26]. Therefore media concentration of $25-\mathrm{OHC}$ can reach $10 \mu \mathrm{g} / \mathrm{mL}$ in approximately 4 days assuming 50 million cells grown in 5 $\mathrm{mL}$ of media. Furthermore, $10 \mu \mathrm{g} / \mathrm{mL}$ was shown by other members of the same laboratory to be ineffective in causing cytotoxicity of Leydig cells, in which 25-OHC is metabolized to form testosterone [27]. Only when Lukyanenko et al (2001) used a concentration of $100 \mu \mathrm{g} / \mathrm{mL}$ over an exposure period of 2 days did they 
observe toxicity to $50 \%$ of Leydig cells [ 27]. To a lesser extent, the bovine ECs in the present study were observed to be resistant to 25-OHC cytotoxic effects at $10 \mu \mathrm{g} / \mathrm{mL}$ over an exposure period of 1 day.

Previously, 25-OHC treatment was shown to increase cell death, increase prostacyclin production (suggestive of cyclooxygenase activity induction), and decrease proliferation when compared to cholesterol treatment [ 28]. The cytotoxicity of 25-OHC on cultured human umbilical arterial ECs was demonstrated by Kawamura and Kummerow to be both concentration and time dependent [ 28]. We have performed a similar examination of 25-OHC cytotoxicity on arterial as well as venous and lymphatic ECs and found that not all EC types were equally affected by 25-OHC exposure and/or celecoxib treatment. BmAECs had the highest level of cell death upon 25-OHC exposure (Figure 3). The effect of celecoxib on bmLECs did not seem to be dependent on 25-OHC exposure (Figure 4a). Furthermore, cells with undetectable levels of endogenous basal Cox-2 like bmAECs and HCT-116 were further sensitized to celecoxib if they were previously exposed to 25-OHC (Figure $4 \mathrm{~b}$ and $4 \mathrm{c}$ ). Our results seem to suggest that effects of 25-OHC may be cell-type dependent in addition to being partially dependent on the status of Cox- 2 expression by the cell.

Our results in Figure 1a corroborate work by others' work establishing 25-OHC as an inducer of Cox-2 expression in ECs $[15,16]$. The fact that during inflammation, Cox-2 expression in ECs is induced by cytokines such as interleukin-1 $\beta$ (IL-1 $\beta$ ) [ 29] released by macrophages, suggests that $25-\mathrm{OHC}$ may be proinflammatory. However, evidence exists indicating that $25-\mathrm{OHC}$ may be anti-inflammatory. This evidence comes from studies of the Liver X Receptor (LXR), for which 25-OHC is an agonistic ligand [ 30]. For example, synthetic LXR agonists have been shown to inhibit IL-1 $\beta$-induced production of Prostaglandin E2 $\left(\mathrm{PGE}_{2}\right)$, as well as Cox-2 in osteoarthritic cartilage and in the synovial sarcoma cell line SW982 [ 31]. For another example, LXR agonists such as GW3965 inhibited expression of pro-inflammatory mediators such as nitric oxide (NO) synthase, Cox-2, and IL-6 in macrophages [ 32]. Although LXRs are also expressed by ECs [ 33], Morello et al (2009) established that pro-inflammatory effects of 25-OHC in ECs are not dependent on LXRs [ 33]. Altogether these studies indicate that 25-OHC may act as an anti-inflammatory agent in an LXRdependent manner in certain tissues and a pro-inflammatory agent in an LXR-independent manner in other tissues, most notably ECs.

Indirectly, 25-OHC has been shown to induce immune cells such as macrophages to express and secrete interleukin-1 $\beta$ (IL-1 $\beta$ ) [ 34], which induces Cox-2 expression in ECs [ 29] as well as in colon cancer cells [ 35]. Macrophages and other immune cells are frequently recruited to the site of tumourigenesis by factors secreted by colon cancer cells [ 36]. Macrophages at the site of tumourigenesis have been shown to activate colon cancer cells by increasing their proliferation and metastasis potential. Activated colon cancer cells in turn stimulate blood ECs to undergo angiogenesis [ 37]. Moreover, 25-OHC in combination with IL-1 $\beta$ has been shown to stimulate human colon carcinoma cells (Caco-2) to produce IL-8 [ 38], which in turn is a promoter of angiogenesis by stimulating endothelial cells proliferation, survival, migration, and MMP-2 production $[39,40]$. Taken together, these results may suggest that $25-\mathrm{OHC}$ at concentrations that are not cytotoxic may participate in colon tumourigenesis with or without Cox-2 involvement, although 25-OHC may cooperate with some tumourigenic effects of Cox-2.

Since 25-OHC is an LXR activating ligand, and since LXR has recently been suggested to inhibit proliferation of breast cancer [ 41], it logically follows that 25-OHC should perhaps be considered to be antitumourigenic. However we suggested in the previous paragraph that 25-OHC may be pro-tumourigenic when it is not cytotoxic. Indeed, we observed that short-term exposure to 25-OHC stimulated EC proliferation, which could be reversed by celecoxib (Figure 2). The apparent conflict can be resolved when the contexts in which effects of 25-OHC on cells are considered. Results by Morello et al (2009) using human umbilical venous endothelial cells led the investigators to suggest that, at least in EC, 25-OHC was not as potent as other oxysterols such as 22-OHC or 24,25-OHC in activating LXR [ 33]. The suggestion by these same investigators that perhaps more prolonged exposure of cells to 25-OHC would lead to more dramatic LXRdependent effects was partly corroborated by our results indicating more prolonged exposure of ECs to 25$\mathrm{OHC}$ was required to cause cytotoxicity (Figure 3 ). All together, these findings suggest that not all effects of 25-OHC on cells are LXR-dependent and mechanistically linked to the induction of Cox-2 and thereby PGE ${ }_{2}$ production. Thus, $25-\mathrm{OHC}$ may still be considered a potential cytotoxic agent with anti-cancer properties despite certain pro-inflammatory characteristics such as the induction of Cox-2 expression.

In health, Cox-2 is normally not constitutively detectable in vascular endothelial cells and epithelial cells of the gastrointestinal tract and is more commonly detected in parts of the brain, kidney, pancreatic islet, ovary and in uterine cells (reviewed in [ 42]). Cox-2 expression is induced in the event of injury by tissues requiring damage repair and at sites of inflammation (reviewed in [ 42]). In colon cancer, Cox-2 has been found to be abnormally over-expressed in about $90 \%$ of colorectal adenocarcinomas and in $40-90 \%$ of colorectal adenomas (reviewed in [ 43]). The abnormal over-expression of Cox-2 is not only found in tumour cells but also in almost every cell type in the surrounding tumour including fibroblasts, myofibroblasts, 
mononuclear inflammatory cells, and most importantly, endothelial cells (reviewed in [ 43]). Expression of Cox-2 in ECs surrounding colorectal tumours has been shown to promote angiogenesis and lymphangiogenesis by mechanisms dependent on PGE 2 production. Products of the enzymatic pathway perform such tasks as promotion of EC proliferation, survival, increasing EC motility towards the tumour, and up-regulation of VEGF-C levels [ 44]. Expression of Cox-2 in ECs can also promote tumourigenesis by mechanisms independent of PGE 2 production such as activation of carcinogens [ 45] and reduction in arachidonic levels [ 46]. These tumourigenic properties of Cox-2 are part of the reason why cyclooxygenase inhibitors are under review as a potential cancer therapy particularly for colon cancer [ 47].

Previously, Penning et al (1997) established $15 \mu \mathrm{M}$ to be the half maximal inhibitory concentration (IC50) of celecoxib for Cox-1 and $0.04 \mu \mathrm{M}$. In this study, we chose to examine effects of low celecoxib concentrations $(5-15 \mu \mathrm{M})$ in order to minimize off-target effects of celecoxib and ensure that most of our observations were due to Cox-2 inhibition. While the choice of dose did allow us to observe some Cox-2-dependent effects, we also found the viability of Cox-2-deficient HCT-116 to be reduced even at these low concentrations (Figure $4 \mathrm{c})$. These results are expected considering that other investigators have demonstrated anti-proliferative effects of celecoxib to extend beyond Cox-2 inhibition in colon cancer cell lines [ 48], hematopoietic and epithelial cell lines [49] and prostate cancer xenografts [ 50].

\section{Conclusions}

Cox-2-dependent effects of 25-OHC on endothelial cell proliferation was transient. Prolonged exposure to 25-OHC caused cell death and enhanced celecoxib-induced cell death in a less Cox-2 dependent manner. More importantly, the three EC types represented by the bovine mesenteric ECs did not respond identically to the Cox-2 inhibitor celecoxib--bmLECs and bmAECs but not bmVECs were sensitive to even $5 \mathrm{uM}$ of celecoxib (Figures 3 and 4 ). Thus, Cox-2 inhibitors as anti-cancer treatments may show cell-type selectivity. Three-cell models such as our primary cultures of bmLECs, bmVECs, and bmAECs can aid examination of the effectiveness of celecoxib on proliferation/cell cycle of different tumour associated ECs. In future experiments, our three EC types extracted from bovine mesentery may also be treated with immune cytokines such as IL- $1 \beta$ and IL-8, in addition to tumourigenic compounds such as $25-\mathrm{OHC}$ to recapitulate activated ECs in the colon tumour environment.

\section{Declarations}

\section{Acknowledgements}

We wish to acknowledge the support of Jamie Jones, Maribelle Cruz, and Sue Santillo. VPKH Nguyen is a recipient of the Banting and Best Canadian Graduate Scholar - Doctoral Award from the Canadian Institute of Health Research (CIHR, 2007-2010). KP, AC, AT, and CM were students at St. Elizabeth Catholic Secondary School. KP, AC, AT, and CM participated in the 2006-2007 annual Sanofi-Aventis Biotech Challenge in the Greater Toronto Area. KP, AC, AT, and CM placed fourth overall. DJ Dumont is a Canadian Research Chair in Angiogenesis and Lymphangiogenesis Signaling. This study was funded by the Heart and Stroke Foundation of Canada (GRANT No.NA5425).

\section{Authors' original submitted files for images}

Below are the links to the authors' original submitted files for images.

Authors' original file for figure 1

Authors' original file for figure 2

Authors' original file for figure 3

Authors' original file for figure 4

Alyssa Cantarutti, Alyssa Terminesi, Cassandra Mendonca contributed equally to this work.

\section{Competing interests}

The authors declare that they have no competing interests. 


\section{Authors' contributions}

VPKHN conceived the ideas, performed experiments, analysed data, produced figures and wrote the paper; $\mathrm{KP}$ contributed to writing the paper and contributed work to experiments; SC performed experiments requiring PCR; AC, AT, and CM contributed work to experiments; DJD contributed to the writing and the development of the project.

\section{References}

1. Fuchs M. Bile acid regulation of hepatic physiology: III. Regulation of bile acid synthesis: past progress and future challenges. Am J Physiol Gastrointest Liver Physiol. 2003;284:G551-557.

View Article Google Scholar

2. Lund EG, Kerr TA, Sakai J, Li WP, Russell DW. cDNA cloning of mouse and human cholesterol 25-hydroxylases, polytopic membrane proteins that synthesize a potent oxysterol regulator of lipid metabolism. J Biol Chem. 1998;273:34316-34327.

View Article Google Scholar

3. Gupta A, Sexton RC, Rudney H. Modulation of regulatory oxysterol formation and low density lipoprotein suppression of 3-hydroxy-3-methylglutaryl coenzyme A (HMG-CoA) reductase activity by ketoconazole. A role for cytochrome P-450 in the regulation of HMG-CoA reductase in rat intestinal epithelial cells. J Biol Chem. 1986;261:8348-8356.

View Article Google Scholar

4. Javitt NB. Cholesterol, hydroxycholesterols, and bile acids. Biochem Biophys Res Commun. 2002;292:1147-1153.

View Article Google Scholar

5. Dzeletovic S, Breuer O, Lund E, Diczfalusy U. Determination of cholesterol oxidation products in human plasma by isotope dilution-mass spectrometry. Anal Biochem. 1995;225:73-80.

View Article Google Scholar

6. Kandutsch AA, Chen HW. Inhibition of sterol synthesis in cultured mouse cells by cholesterol derivatives oxygenated in the side chain. J Biol Chem. 1974;249:6057-6061.

View Article Google Scholar

7. Adams CM, Reitz J, De Brabander JK, Feramisco JD, Li L, Brown MS, Goldstein JL. Cholesterol and 25-hydroxycholesterol inhibit activation of SREBPs by different mechanisms, both involving SCAP and Insigs. J Biol Chem. 2004;279:52772-52780.

View Article Google Scholar

8. Gill S, Chow R, Brown AJ. Sterol regulators of cholesterol homeostasis and beyond: the oxysterol hypothesis revisited and revised. Prog Lipid Res. 2008;47:391-404.

View Article Google Scholar

9. Larsson O, Zetterberg A. Existence of a commitment program for mitosis in early G1 in tumour cells. Cell Prolif. 1995;28:33-43.

View Article Google Scholar

10. Wang JH, Tuohimaa P. Regulation of cholesterol 25-hydroxylase expression by vitamin D3 metabolites in human prostate stromal cells. Biochem Biophys Res Commun. 2006;345:720-725. View Article Google Scholar

11. Ayala-Torres S, Moller PC, Johnson BH, Thompson EB. Characteristics of 25-hydroxycholesterolinduced apoptosis in the human leukemic cell line CEM. Exp Cell Res. 1997;235:35-47.

View Article Google Scholar 
12. Ayala-Torres S, Zhou F, Thompson EB. Apoptosis induced by oxysterol in CEM cells is associated with negative regulation of c-myc. Exp Cell Res. 1999;246:193-202.

View Article Google Scholar

13. Harada K, Ishibashi S, Miyashita T, Osuga J, Yagyu H, Ohashi K, Yazaki Y, Yamada N. Bcl-2 protein inhibits oxysterol-induced apoptosis through suppressing CPP32-mediated pathway. FEBS Lett. 1997;411:63-66.

View Article Google Scholar

14. Yang L, Sinensky MS. 25-Hydroxycholesterol activates a cytochrome c release-mediated caspase cascade. Biochem Biophys Res Commun. 2000;278:557-563.

View Article Google Scholar

15. Wohlfeil ER, Campbell WB. 25-Hydroxycholesterol enhances eicosanoid production in cultured bovine coronary artery endothelial cells by increasing prostaglandin $\mathrm{G} / \mathrm{H}$ synthase-2. Biochim Biophys Acta. 1997;1345:109-120.

View Article Google Scholar

16. Wohlfeil ER, Campbell WB. 25-hydroxycholesterol increases eicosanoids and alters morphology in cultured pulmonary artery smooth muscle and endothelial cells. Arterioscler Thromb Vasc Biol. 1999;19:2901-2908.

View Article Google Scholar

17. Colleselli D, Bijuklic K, Mosheimer BA, Kahler CM. Inhibition of cyclooxygenase (COX)-2 affects endothelial progenitor cell proliferation. Exp Cell Res. 2006;312:2933-2941.

View Article Google Scholar

18. Yazawa K, Tsuno NH, Kitayama J, Kawai K, Okaji Y, Asakage M, Sunami E, Kaisaki S, Hori N, Watanabe T, et al. Selective inhibition of cyclooxygenase (COX)-2 inhibits endothelial cell proliferation by induction of cell cycle arrest. Int J Cancer. 2005;113:541-548.

View Article Google Scholar

19. Nguyen VP Chen SH Trinh J Kim H Coomber BL Dumont DJ Differential response of lymphatic, venous and arterial endothelial cells to angiopoietin-1 and angiopoietin-2 BMC Cell Biol 20078 101828055 10.1186/1471-2121-8-10

20. Molina MA, Sitja-Arnau M, Lemoine MG, Frazier ML, Sinicrope FA. Increased cyclooxygenase-2 expression in human pancreatic carcinomas and cell lines: growth inhibition by nonsteroidal anti-inflammatory drugs. Cancer Res. 1999;59:4356-4362.

View Article Google Scholar

21. Dvory-Sobol H, Cohen-Noyman E, Kazanov D, Figer A, Birkenfeld S, Madar-Shapiro L, Benamouzig R, Arber N. Celecoxib leads to G2/M arrest by induction of p21 and downregulation of cyclin B1 expression in a p53-independent manner. Eur J Cancer. 2006;42:422-426. View Article Google Scholar

22. Vane JR, Bakhle YS, Botting RM. Cyclooxygenases 1 and 2. Annu Rev Pharmacol Toxicol. 1998;38:97-120.

View Article Google Scholar

23. Jung HJ, Shim JS, Suh YG, Kim YM, Ono M, Kwon HJ. Potent inhibition of in vivo angiogenesis and tumor growth by a novel cyclooxygenase- 2 inhibitor, enoic acanthoic acid. Cancer Sci. 2007;98:1943-1948.

View Article Google Scholar

24. Toker M Bagcivan I Topalkara A Karadas B Durmus N Parlak A Kaya T Nifedipine enhances the relaxant effects of cyclo-oxygenase inhibitors on the bovine ciliary muscle J Ocul Pharmacol Ther 20082465375412958440 10.1089/jop.2007.0129 
25. Myers KM, Coudrillier B, Boyce BL, Nguyen TD. The inflation response of the posterior bovine sclera. Acta Biomater. 2010;6:4327-4335.

View Article Google Scholar

26. Nes WD, Lukyanenko YO, Jia ZH, Quideau S, Howald WN, Pratum TK, West RR, Hutson JC. Identification of the lipophilic factor produced by macrophages that stimulates steroidogenesis. Endocrinology. 2000;141:953-958.

View Article Google Scholar

27. Lukyanenko YO, Chen JJ, Hutson JC. Production of 25-hydroxycholesterol by testicular macrophages and its effects on Leydig cells. Biol Reprod. 2001;64:790-796.

View Article Google Scholar

28. Kawamura K, Kummerow FA. Effect of 25-hydroxycholesterol on cytotoxicity and prostacyclin production in cultured human umbilical arterial endothelial cells. Eicosanoids. 1992;5:29-34.

View Article Google Scholar

29. Uracz W, Uracz D, Olszanecki R, Gryglewski RJ. Interleukin 1beta induces functional prostaglandin E synthase in cultured human umbilical vein endothelial cells. J Physiol Pharmacol. 2002;53:643-654.

View Article Google Scholar

30. Janowski BA Grogan MJ Jones SA Wisely GB Kliewer SA Corey EJ Mangelsdorf DJ Structural requirements of ligands for the oxysterol liver X receptors LXRalpha and LXRbeta Proc Natl Acad Sci USA 199996126627115128 10.1073/pnas.96.1.266

31. Li N Rivera-Bermudez MA Zhang M Tejada J Glasson SS Collins-Racie LA Lavallie ER Wang Y Chang KC Nagpal S LXR modulation blocks prostaglandin E2 production and matrix degradation in cartilage and alleviates pain in a rat osteoarthritis model Proc Natl Acad Sci USA 20101078373437392840473 10.1073/pnas.0911377107

32. Joseph SB, Castrillo A, Laffitte BA, Mangelsdorf DJ, Tontonoz P. Reciprocal regulation of inflammation and lipid metabolism by liver X receptors. Nat Med. 2003;9:213-219.

View Article Google Scholar

33. Morello F, Saglio E, Noghero A, Schiavone D, Williams TA, Verhovez A, Bussolino F, Veglio F, Mulatero P. LXR-activating oxysterols induce the expression of inflammatory markers in endothelial cells through LXR-independent mechanisms. Atherosclerosis. 2009;207:38-44. View Article Google Scholar

34. Rosklint T, Ohlsson BG, Wiklund O, Noren K, Hulten LM. Oxysterols induce interleukin-1beta production in human macrophages. Eur J Clin Invest. 2002;32:35-42.

View Article Google Scholar

35. Duque J, Diaz-Munoz MD, Fresno M, Iniguez MA. Up-regulation of cyclooxygenase-2 by interleukin-1beta in colon carcinoma cells. Cell Signal. 2006;18:1262-1269.

View Article Google Scholar

36. Zins K, Abraham D, Sioud M, Aharinejad S. Colon cancer cell-derived tumor necrosis factoralpha mediates the tumor growth-promoting response in macrophages by up-regulating the colony-stimulating factor-1 pathway. Cancer Res. 2007;67:1038-1045.

View Article Google Scholar

37. Jedinak A, Dudhgaonkar S, Sliva D: Activated macrophages induce metastatic behavior of colon cancer cells. Immunobiology. 215 (3): 249-242. 
38. Bai B, Yamamoto K, Sato H, Sugiura H, Tanaka T. Combined effect of 25-hydroxycholesterol and IL-1 beta on IL-8 production in human colon carcinoma cell line (Caco-2). Inflammation. 2005;29:141-146.

View Article Google Scholar

39. Li A, Varney ML, Valasek J, Godfrey M, Dave BJ, Singh RK. Autocrine role of interleukin-8 in induction of endothelial cell proliferation, survival, migration and MMP-2 production and angiogenesis. Angiogenesis. 2005;8:63-71.

View Article Google Scholar

40. Li A, Dubey S, Varney ML, Dave BJ, Singh RK. IL-8 directly enhanced endothelial cell survival, proliferation, and matrix metalloproteinases production and regulated angiogenesis. J Immunol. 2003;170:3369-3376.

View Article Google Scholar

41. Vedin LL, Lewandowski SA, Parini P, Gustafsson JA, Steffensen KR. The oxysterol receptor LXR inhibits proliferation of human breast cancer cells. Carcinogenesis. 2009;30:575-579.

View Article Google Scholar

42. Turini ME, DuBois RN. Cyclooxygenase-2: a therapeutic target. Annu Rev Med. 2002;53:35-57. View Article Google Scholar

43. Wendum D, Masliah J, Trugnan G, Flejou JF. Cyclooxygenase-2 and its role in colorectal cancer development. Virchows Arch. 2004;445:327-333.

View Article Google Scholar

44. Su JL, Shih JY, Yen ML, Jeng YM, Chang CC, Hsieh CY, Wei LH, Yang PC, Kuo ML.

Cyclooxygenase-2 induces EP1- and HER-2/Neu-dependent vascular endothelial growth factor-C up-regulation: a novel mechanism of lymphangiogenesis in lung adenocarcinoma. Cancer Res. 2004;64:554-564.

View Article Google Scholar

45. Wiese FW, Thompson PA, Kadlubar FF. Carcinogen substrate specificity of human COX-1 and COX-2. Carcinogenesis. 2001;22:5-10.

View Article Google Scholar

46. Brock TG, McNish RW, Peters-Golden M. Arachidonic acid is preferentially metabolized by cyclooxygenase-2 to prostacyclin and prostaglandin E2. J Biol Chem. 1999;274:11660-11666. View Article Google Scholar

47. Wang D, Dubois RN: The role of COX-2 in intestinal inflammation and colorectal cancer. Oncogene. 29 (6): 781-788. 10.1038/onc.2009.421.

48. Grosch S, Tegeder I, Niederberger E, Brautigam L, Geisslinger G. COX-2 independent induction of cell cycle arrest and apoptosis in colon cancer cells by the selective COX-2 inhibitor celecoxib. FASEB J. 2001;15:2742-2744.

View Article Google Scholar

49. Waskewich C, Blumenthal RD, Li H, Stein R, Goldenberg DM, Burton J. Celecoxib exhibits the greatest potency amongst cyclooxygenase (COX) inhibitors for growth inhibition of COX-2negative hematopoietic and epithelial cell lines. Cancer Res. 2002;62:2029-2033.

View Article Google Scholar

50. Patel MI, Subbaramaiah K, Du B, Chang M, Yang P, Newman RA, Cordon-Cardo C, Thaler HT, Dannenberg AJ. Celecoxib inhibits prostate cancer growth: evidence of a cyclooxygenase-2independent mechanism. Clin Cancer Res. 2005;11:1999-2007.

View Article Google Scholar 
